\title{
A ética política de Merleau-Ponty : 0 problema do humanismo
}

\author{
Guillaume Carron \\ carron.guillaume2@wanadoo.fr \\ Professor agrégé do Lycée Monge de Chambéry, Chambéry, França
}

\begin{abstract}
resumo Neste artigo, tentamos definir alguns aspectos de uma ética política na filosofia de Merleau-Ponty. É possivel descrever um problema recorrente e estrutural em seu trabalho político: a questão do "humanismo". Este problema implica que o objetivo de qualquer ação política consiste na "instituição" de um vínculo simbólico entre os seres humanos. Argumentamos que o problema do humanismo estrutura o pensamento político do filósofo e explica a relação de Merleau-Ponty com o marxismo e a história. A intrepidez da instituição, que pode ser uma resposta ao problema do humanismo, encarna a virtude política fundamental. Virtude que Merleau-Ponty denomina "virtude sem qualquer resignação".
\end{abstract}

palavras-chave instituição; humanismo; virtude; contingência

\begin{abstract}
«Qualquer que seja a filosofia que se professe, mesmo a teológica, uma sociedade não é o templo dos valores-ídolos que figuram no frontão de seus monumentos ou nos textos de sua constituição, ela vale o que nela valem as relações do homem com o homem» (MERLEAU-PONTY 2010, p.186)
\end{abstract}

Geralmente Merleau-Ponty não é lembrado por ser um pensador muito engajado. Ao contrário de Sartre, não se pode dizer que ele tenha tomado parte de maneira ostensiva e constante nas grandes manifestações políticas de seu tempo. Além disso, sem dúvida a comparação com seu amigo Sartre contribui para amenizar as diferentes formas de implicações nas quais ele pôde tomar parte ao longo de sua vida. $\mathrm{O}$ mais estranho é 
que tal dúvida quanto ao engajamento político de Merleau-Ponty parece não apenas tocar sua biografia, mas, também, em certa medida, sua obra. Por certo, alguns pensadores se inspiraram em conceitos merleaupontyanos para fundar sua própria filosofia política. Lembremo-nos de Castoriadis por exemplo. Mas não existe verdadeiramente uma abordagem sistemática do pensamento político de Merleau-Ponty, nem uma análise verdadeiramente detalhada dos valores que ele defendia.Tal aspecto pode parecer surpreendente, uma vez que Merleau-Ponty sempre reivindicou uma filosofia " concreta ", ancorada na atualidade, e vale constatar que nenhum de seus escritos políticos podem ser separados de uma reflexão precisa sobre os conflitos ideológicos e sociais de sua época. Tampouco se pode dizer que o filósofo francês escondia suas posições, uma vez que, malgrado seu distanciamento do comunismo depois de alguns anos, ele sempre considerou o pensamento de Marx como digno do maior interesse e sempre condenou os princípios do pensamento liberal e as derivas do capitalismo. Como, então, compreender a persistência desta imagem de um pensador político um pouco vago, cuja lucidez é frequentemente reconhecida, mas do qual se distancia quando se fala de engajamento político?

Uma das explicações, deve-se, sem duvida, à dificuldade da filosofia merleau-pontyana da história. O autor de Humanisme et terreur (Ed. Brasileira: Humanismo e terror. Tempo brasileiro, 1968) propõe uma abordagem complexa, guiada pela exigência do concreto, isto é, pela constante colocação das relações entre as teorias e os resultados efetivos de sua aplicação. Ele também tenta compreender o entrelaçamento, no acontecimento, das ideias e dos fatos. Neste contexto, por vezes é pouco confortável apreender efetivamente o cunho ideológico de suas análises, bem como a posição que ele mesmo ocupa em relação às suas próprias críticas: trata-se apenas de analisar a atualidade, de explicá-la à luz dos conceitos da filosofia, independentemente de tomar qualquer partido ideológico? Ou pode-se falar de uma verdadeira filosofia política, ideologicamente fundada, traduzindo-se na prática por um engajamento sem falha nem compromisso? Gostaríamos sem dúvida de responder tais questões de maneira esmiuçada, para enfim compreender onde MerleauPonty estaria situado. $\mathrm{Na}$ verdade, pensamos que nenhuma delas podem verdadeiramente contornar a reflexão política do filósofo, precisamente 
porque esta última introduz uma forma de descompasso entre a ideologia e o engajamento. Com efeito, como condição para compreender o problema estrutural que anima o pensamento de Merleau-Ponty, nós constataremos que sua abordagem tenta ultrapassar a simples ideologia, para definir não mais uma forma de militância, mas uma verdadeira ética política, centrada sobre uma caracterização muito precisa da "virtude ».

Mais precisamente, a finalidade primeira de nossa exposição consiste em mostrar que a obra política de Merleau-Ponty é atravessada por um só e mesmo problema: o problema do " humanismo ", que aparece sob sua formulação mais clara na Note sur Machiavel («Nota sobre Maquiavel»). Esse problema não interroga a fundação do político nem à luz de uma certa visão do homem, nem em função do que a humanidade deveria ser ; coloca, antes, o engajamento na construção do laço simbólico e histórico entre os homens como exigência soberana. No limite, quase se poderia pensar que a natureza desse vínculo pouco importa, a partir do momento em que ele permite nossa coexistência efetiva. A ética merleau-pontyana não se inscreve na perseguição de valores definidos, mas numa certa atitude em relação aos valores. Esse ligeiro deslocamento de acento é o suficiente para romper com a maior parte das filosofias políticas existentes. Já não se trata, com efeito, de estudar a natureza do homem para fundar a política a partir dela, mas de encontrar uma forma de engajamento que persiste, a despeito da imprevisibilidade dos homens e dos acontecimentos. Após ter bem desenvolvido a significação do problema do humanismo e mostrado seu aspecto estruturante na obra de Merleau-Ponty, nós veremos como pode ser valorizado a partir disso uma certa ética do engajamento ; uma ética que Merleau-Ponty designa pela expressão muito forte, mas também muito enigmática, de «virtude sem nenhuma resignação».

Apesar da evolução de suas tomadas de posição ideológicas, uma mesma preocupação " humanista " atravessa os diferentes escritos políticos do filósofo, qualquer que seja a época de sua elaboração: como o encontro entre os homens, cuja natureza e consequências são imprevisíveis na 


\section{4}

medida em que nenhuma visão do homem poderia determiná-lo de maneira eterna, pode conduzir à criação de um laço simbólico, unindoos no seio de uma história comum? La guerre a eи lieu (1945), Pour la vérité (1946), Autour du Marxisme (1946) ou ainda, evidentemente, Humanisme et terreur (1947), já são habitadas por esta questão de maneira mais ou menos explícita ${ }^{1}$. Mesmo os escritos mais tardios, como Les aventures de la dialectique ou o prefácio de Signes parecem girar em torno da interrogação " humanista ». Todavia, antes de entrar nesses textos, leiamos inicialmente a Note sur Machiavel, que reveste, de acordo com o nosso ponto de vista, a obra política de Merleau-Ponty de um estatuto particular. A interpretação brilhante dos textos do florentino não é a única razão do interesse contido na conferência de 1949. A « nota » revela também a origem conceitual do problema do " humanismo ", a partir da leitura merleaupontyana de Le Prince e dos Discorsi. O que significa, portanto, o termo «humanismo» para Merleau-Ponty, e em que ele constitui o coração de sua reflexão ética?

Se chamarmos de humanismo uma filosofia que encara como um problema a relação do homem com o homem, e a constituição entre eles de uma situação e de uma história que lhes é comum, então é preciso dizer que Maquiavel formulou algumas condições de todo humanismo sério. (MERLEAU-PONTY 2010, p.1476)

Merleau-Ponty não tarda em ver em Maquiavel o primeiro teórico de um humanismo verdadeiro. A amoralidade bem conhecida do florentino, longe de reduzir a política à mera questão estratégica da tomada de poder, abriria a porta para uma nova ética política. Compreender esta interpretação, tão particular, supõe inicialmente esclarecer o que Merleau-Ponty entende por humanismo. Dois traços principais são colocados em xeque: o humanismo pressupõe, em primeiro lugar, considerar "a relação homem a homem " como um " problema » para, em seguida, « constituir entre eles uma história que lhes seja comum ». Esses dois aspectos já revelam certa originalidade. A política não repousaria sobre uma visão da natureza humana, mas sobre o caráter enigmático da relação do homem consigo mesmo e com os outros. Ela deve ser construída a partir do encontro intersubjetivo e do mistério representado pela experiência da alteridade. Em que Maquiavel pode ser precursor de tal pensamento, dito « humanista »? 
É surpreendente como, à primeira vista, o autor do Príncipe é mais conhecido por ter trazido à luz a natureza calculista e interessada do ser humano do que por ter sublinhado suas eventuais virtudes. Mas esse maquiavelismo de superficie esquece que o ponto fundamental do Príncipe não consiste em definir o homem, mas em determinar a estratégia mais eficaz para garantir a estabilidade do poder. Maquiavel não pensa que um dirigente possa antecipar as consequências da relação de forças entre os homens à luz de uma suposta "natureza humana ». Cada situação, cada encontro, tem sua singularidade e deve ser considerado em si mesmo. É porque Maquiavel pode parecer paradoxal em suas abordagens antropológicas. Às vezes ele enuncia, a respeito do homem, várias regras com aspecto de verdades gerais, mesmo sendo contraditórias entre si. Por exemplo, a afeição, a admiração, mesmo o amor dedicado a um governante, são tanto percebidos como sentimentos fortes, impedindo toda forma de ingratidão do sujeito em relação ao príncipe, quanto como sentimentos fracos e prontamente esquecidos, quando o interesse pessoal está em questão ${ }^{2}$. Mas essas contradições efetivamente têm sentido. Elas ilustram a inconstância humana e a impossibilidade de fundar a vida política sobre um pensamento ideal do homem. Não por que o ser humano seria fundamentalmente mal, mas porque ele permanece imprevisível. Assim, quando Maquiavel aconselha o «Príncipe » a jamais contar com a boa fé dos homens e o convida a considerá-los todos como mal intencionados, ele não constrói uma antropologia, mas uma técnica de governo que tenha maior probabilidade de eficácia. É melhor governar como se todo homem fosse mal, porque é impossível prever com certeza as reações de um individuo face à " fortuna ». A virtude política se caracteriza sempre em relação a uma situação particular. Ela consiste essencialmente numa lucidez sobre as circunstâncias e numa faculdade de adaptação e antecipação. Longe de toda consideração ideal sobre a essência do homem, o autor de O príncipe repõe assim no coração da política o papel fundamental da contingência.

Esta contingência é a ideia principal que Merleau-Ponty retém de Maquiavel. Para o filósofo francês, o "humanismo » e os valores que a definem não são dados com o homem, mas nascem do contexto singular e imprevisível de um encontro intersubjetivo. $\mathrm{O}$ « humanismo » se elabora na experiência da alteridade. A singularidade desta abordagem nos leva 
a afastar Merleau-Ponty das teorias do contrato e de toda referência à ficção de um « estado de natureza ».A consideração da contingência acarreta a reintrodução do espanto acerca da natureza humana e convida à desconfiança em face do que se denomina " estado de natureza " na tradição da filosofia política. Esta última não seria efetivamente o pretexto de uma certa definição do homem decorrente de uma ideologia determinada de antemão? Por exemplo, é verdadeiramente a violência inata ao homem que justifica a necessidade de se estabelecer um poder absoluto? Não é antes o desejo de um tal poder que, em certas circunstâncias, enraíza dogmaticamente a violência na natureza humana para legitimar sua existência? Mesmo se a história fornece tantas ilustrações da relação conflituosa entre os homens, isso é o suficiente para suprimir totalmente outras formas de movimentos espontâneos de solidariedade ou de coexistência pacífica que poderiam ter existido? Por que o homem seria espontaneamente mais voltado à violência e ao medo do que à calma e à paz; mais ao sabor da liberdade que ao da igualdade... etc? Não há razão alguma para se conceber a relação imediata entre os homens como essencialmente pacífica ou beligerante. A teoria da contingência significa que não há sentido em definir o homem independentemente da particularidade das situações e que a humanidade inteira está por se fazer. Merleau-Ponty se atém particularmente a esta última ideia ao dizer: «A ideia de uma humanidade fortuita e que não tem causa ganha é o que confere valor absoluto à nossa virtude ». Compreende-se então a exigência que acompanha o "problema da relação do homem com o homem »: constituir entre eles uma história que lhes seja comum. Merleau-Ponty tenta uma definição da virtude política que não se funda sobre uma visão do homem, mas sobre a exigência de construir uma certa humanidade através da contingência fundamental da história. A questão ética não reside apenas nos valores defendidos, mas na capacidade de ligar os homens de maneira efetiva. O humanismo de Merleau-Ponty concede, portanto, um grande lugar à contingência e à implicação de cada um através de sua liberdade política. Ele não se caracteriza fundamentalmente pela defesa de certa ideologia, mas, sobretudo, pela força de um engajamento: o de construir entre os homens o vínculo simbólico que permitirá a definição de uma " humanidade ». 
Pensamos que esta abordagem do « humanismo » estrutura o conjunto do pensamento político de Merleau-Ponty. Duas razões essenciais nos conduzem à afirmá-lo. A primeira é que a consideração do problema do humanismo encarna por si o critério que distingue toda política séria. A segunda é o vínculo entre o problema do humanismo e o conceito fundamental de "instituição», vínculo no qual transparece a questão ética do engajamento. Nós desenvolvemos essas duas razões sucessivamente.

Na citação precedente, extraída da Nota sobre Maquiavel, MerleauPonty fala também de um humanismo "sério ", subentendendo, aqui, que outras formas de discurso políticos reivindicariam a denominação de «humanismo» sem realizar as exigências de tal engajamento. Pala ele, a questão do humanismo não é fundamentalmente ideológica; ela é bem mais que isso. Ela constitui a marca de um pensamento realmente político, porque ela sempre coloca em primeiro plano o problema da experiência do outro e o encargo da coexistência dos homens. A importância deste critério é patente no posicionamento do filósofo francês. É por esta razão, por exemplo, que ele jamais aderiu ao pensamento liberal ${ }^{3}$. Aos seus olhos, crer que o vínculo entre os homens possa ser o resultado miraculoso (" a mão invisível ») da procura individual do interesse, reconduz a uma esquiva do problema fundamental da política. A questão da relação do homem com o homem não é enfrentada, mas previamente regulada pela crença na harmonização mágica dos interesses. MerleauPonty passa finalmente bem rápido pelos problemas colocados pelo pensamento liberal. Poder-se-á, talvez, reprová-lo por não se deter mais sobre os grandes pensadores desta tradição ou de não se estender na discussão conceitual com eles. Mas, na verdade, esta condenação rápida do liberalismo é coerente com o critério do humanismo. Para MerleauPonty, a ameaça do liberalismo reside menos nos valores que defende do que na dimensão a-política de sua reflexão.

A importância do critério do humanismo se vê confirmada pelo estudo das relações de Merleau-Ponty com o marxismo. As mudanças de ponto de vista do filósofo a respeito dessa ideologia testemunha a relação complexa que ele mantém com ela. Embora suscitando algumas expectativas, o marxismo também lhe inspirará certa desconfiança. Mas é por 


\section{8}

uma só razão, profundamente ligada à questão humanista, que ele deposita inicialmente suas esperanças em Marx e dele se afasta posteriormente. Nos primeiros tempos de sua filosofia, Merleau-Ponty tem uma grande afinidade com a teoria marxista, porque ela enfrenta o enigma da relação com o outro. A dificuldade da relação entre os homens está no próprio coração da teoria de Marx, uma vez que este último vê no conjunto dos valores sociais uma ideologia encobrindo a complexidade das relações reais entre os homens. A relação problemática e concreta do homem com o homem é portanto reconduzida ao centro da reflexão política. Mas Merleau-Ponty propõe nesse momento uma interpretação um pouco particular do marxismo. Ele insiste menos sobre a relação de causalidade existente entre a dimensão material e o campo dos valores do que sobre a indissociabilidade entre esses dois aspectos (sem necessariamente introduzir a precedência de um sobre o outro). Esse deslocamento de acento mostra que a questão do humanismo orienta sua perspectiva de leitura, uma vez que ele permite inscrever o marxismo no problema específico da efetividade dos valores. O marxismo não é mais compreendido como uma análise genealógica da ideologia a partir das relações inerentes à luta de classes, mas como uma tentativa de concretizar a moral e de construir um vínculo real entre os homens. Eis o que Merleau-Ponty escreve em 1946 em Pour la vérité:

A ideia mestra do marxismo não é a de sacrificar os valores aos fatos, a moral ao realismo, mas a de substituir a moral efetiva à moral verbal que precede a revolução, é fazer uma sociedade onde a moral seja moral e de destruir a moral como sonho fora das coisas, realizando-a nas relações efetivas dos homens. (MERLEAU-PONTY 2010, p.141)

Portanto, Merleau-Ponty é seduzido pelo pensamento marxista porque acredita ver nele a resposta ao problema do humanismo. Todavia, a exigência do concreto supõe não permanecer na « ideia mestra do marxismo ", mas interrogar a aplicação que dela é feita, isto é, o comunismo. Assim, um ano mais tarde, em Humanismo e terror, o filósofo francês se pergunta se a crença se revela fundada: " $\mathrm{O}$ comunismo equivale às suas intenções humanistas? Eis é a verdadeira questão " (MERLEAUPONTY 2010, p.188).Vários comentadores e leitores já sublinharam que a resposta trazida por Merleau-Ponty para esta questão atenuava demais a 
realidade da violência comunista da época ${ }^{4}$. É provável que a proximidade temporal dos fatos relatados em Humanismo e terror impedisse uma lucidez completa sobre os acontecimentos; e, deste ponto de vista, Merleau-Ponty tampouco foi o menos perspicaz. Não obstante, o fato de não avaliar toda dimensão desta violência é também, sem dúvida, o sintoma de uma dificuldade com a qual Merleau-Ponty se confrontava naquele momento. A exigência do concreto o colocava numa situação paradoxal. De um lado, Merleau-Ponty estava seduzido pelo conceito marxista de "proletariado ", que trazia uma resposta à questão do humanismo. O proletário era, segundo ele, um sujeito político para quem o exercício da liberdade individual é absolutamente indissociável da preocupação de criar um vínculo com outrem. « No proletário a individualidade ou a consciência de si e a consciência de classe são absolutamente idênticas » (MERLEAU-PONTY 2010, p.288). «A alternativa do real e do ideal é ultrapassada na concepção do proletariado como portador concreto dos valores"(MERLEAU-PONTY 2010, p.295). Nesse sentido, o proletariado encarna o próprio lugar do político, uma vez que coloca sem cessar através dele o problema do vínculo entre os homens. Todavia, por outro lado, a história concreta mostra que a tomada de poder do proletariado não se efetua sem violência e desemboca, além disso, no reestabelecimento do poder opressor de alguns sobre a maioria. O lugar ocupado pela violência no nascimento do comunismo efetivo coloca manifestamente um problema para Merleau-Ponty. Como conciliar violência e humanismo? Sobre esta questão, a posição de MerleauPonty logo abre mão e revela certa ambivalência. A esperança que, sem dúvida, o comunismo representa para ele nessa época leva-o a ocultar o problema da origem da violência e a considerá-la, logo de cara, como um componente natural das relações humanas.

A violência é nosso quinhão na medida em que somos encarnados... A violência é a situação de partida comum a todos os regimes. A vida, a discussão e a escolha política só têm lugar sobre este fundo. O que conta e o que vale discutir, não é a violência, é seu sentido ou seu futuro (MERLEAU-PONTY 2010, p.285).

O simples fato de ter um corpo nos enraizaria na violência. Não se trata de contestar a onipresença da violência nas relações humanas, mas podemos 
perguntar se Merleau-Ponty não reconduz, aqui, ao pressuposto de uma «natureza» humana, e se ele segue até o final a exigência trazida pelo humanismo, a saber, a aceitação da contingência. Fundar as relações humanas sobre uma violência original regressa, em certa medida, a correr o risco de transformar uma situação talvez contingente numa necessidade real. Dito de outro modo, constituindo inteiramente o cerne da primeira aproximação merleau-pontyana com o marxismo, o problema do humanismo não é percebido em toda a sua extensão no fim dos anos 40 .

Em meados dos anos cinquenta, Merleau-Ponty não abandona completamente a ideia de uma violência natural das relações humanas, mas se distancia um pouco dela emprestando doravante esta concepção de Weber (MERLEAU-PONTY 2010, p.416). Desde então, sua visão do marxismo se encontra logicamente modificada. Uma dúvida se instala quanto à verdadeira capacidade do conceito de "proletariado ", como resposta ao problema do humanismo.

As políticas, sejam de entendimento ou de razão, são um vai-e-vem entre o real e os valores, o julgamento solitário e a ação comum, o presente e o futuro e, mesmo se pensarmos, como Marx, que elas estão reunidas em um fator histórico, o proletariado, ao mesmo tempo potência e valor, como pode dele haver discordância sobre o modo de fazê-lo entrar em cena e tomar posse da história, a política marxista é, como todas as outras, indemonstrável. A diferença é apenas que ela sabe disso, e que, mais que qualquer outra, explorou o labirinto.

(MERLEAU-PONTY 2010, p.414)

"Como pode dele haver discordância sobre o modo fazer ": enquanto Merleau-Ponty via anteriormente a violência do comunismo como a expressão da natureza humana no campo político, ele admite doravante que esta violência poderia não existir. Enfim, ele reintroduz a contingência. Mais que qualquer outro, Marx enfrentou o problema do humanismo, mas a resposta que a ele trouxe no conceito de proletariado não pode mais funcionar nos dias de hoje. Portanto, é em nome do problema do humanismo que Merleau-Ponty adere à Marx, mas também em seu nome que se afasta do comunismo, em As aventuras da dialética. $\mathrm{O}$ uso da violência, ligada ao quadro revolucionário, não é mais um dado primário das relações humanas, mas responde a uma certa lógica de circunstâncias. 
Os marxistas bem o sabem, quando eles dizem que a ditadura do proletariado volta contra a burguesia as armas da burguesia. Mas então uma filosofia proletária da história consiste em postular esse milagre que a ditadura emprega as armas da burguesia sem se tornar algo como uma burguesia, que uma classe dirige sem decadência, quando toda classe que rege o todo se constata, por isso mesmo, particular, que uma formação histórica, o proletariado, possa ser instituída em classe dirigente sem retomar as subordinações do papel histórico... A ditadura do proletariado, mesmo se nela supomos a missão absoluta de implantar na história as relações do homem com o homem, tais como o proletariado as descobre, só concluirá este trabalho na ambiguidade, com a dispersão de energia, que são inseparáveis do poder e da generalidade social. Supor que o proletariado defenderá sua ditadura contra a involução, é supor na própria história um princípio substancial e dado que nela caça a ambiguidade, a resume, a totaliza e a fecha..., e quem quer que suponha este princípio e empreenda colocá-lo no poder concede no mesmo gesto a investidura a um poder impuro. (MERLEAU-PONTY 2010, pp.611-612)

A crítica do conceito marxista de "proletariado " se faz em nome do retorno à uma ambiguidade fundamental da história, da impossibilidade de se referir a uma natureza dada das relações humanas que permitiriam definir para sempre o futuro e o sentido do político ; o que MerleauPonty mesmo faria em Humanismo e terror quando ele considerava a violência como o elemento constitutivo de nossa experiência de alteridade. O humanismo supõe que não há natureza humana se esta não é aquela que o homem institui segundo a "qualità dei tempi ", para parafrasear Maquiavel.

Assim, a condenação rápida do liberalismo, em razão de sua dimensão apolítica, e a crítica do marxismo, que atravessa a reflexão de Merleau-Ponty, têm por fundamento uma fidelidade cada vez maior às exigências do humanismo. Aqui está uma das razões fundamentais que nos leva a ver neste último a estrutura subjacente do pensamento político do filósofo francês.

Uma segunda razão vem confirmar esta perspectiva. O nascimento de uma « história comum », que constitui o segundo aspecto do humanismo, não é outra coisa senão aquilo que Merleau-Ponty chamará, nos cursos 
de 1954, uma "instituição ", isto é, uma experiência a partir da qual as outras experiências (minhas ou de outrem) tomarão um sentido e formarão uma continuidade, uma história. O que é preciso, aqui, entender por " história » e "instituição »?

A instituição, no sentido forte, é esta matriz simbólica que faz com que haja abertura de um campo, de um futuro segundo dimensões, donde possibilidade de uma aventura comum e de uma história como consciência. (MERLEAU-PONTY 2003, p.45)

A história da qual fala aqui Merleau-Ponty se encarna na dimensão simbólica partilhada pelos homens e através da qual sua vida se desenrola. A proximidade conceitual entre o enunciado da questão humanista e a definição da instituição contribui para conceder um valor filosófico fundamental ao humanismo. Este último não é apenas um tomar partido político entre outros, ele encarna o político enquanto tal, isto é, o campo no seio do qual toda problemática ideológica se coloca. A instituição encarna, para Merleau-Ponty, o lugar dos valores, o próprio meio da história, como ele escreve no mesmo período de seus cursos sobre a instituição em As aventuras da dialética.

Para compreender, ao mesmo tempo, a lógica da história e seus contornos, seu sentido e o que nela resiste ao sentido, deles permanecia por conceber seu meio próprio, a instituição, que se desenvolve não segundo leis causais, como uma outra natureza, mas sempre de maneira dependente do que ela significa, e não apenas segundo ideias eternas, mas conduzindo mais o ou menos sob a lei dos acontecimentos fortuitos que lhe dizem respeito, se deixando mudar por suas sugestões. Destrinçada por todas as contingências, reparada pelo gesto revolucionário dos homens que dela se ocupam e querem viver, a trama não merece nem o nome de espírito nem aquele de matéria, mas justamente o de história. (MERLEAU-PONTY 2003, p.45)

Reencontramos aqui, na definição mesma de instituição, o tema fundamental da contingência, característica do humanismo, e que impede toda consideração da história como porvir regido por um princípio ideal. Pensamos que a aproximação de questões políticas com a noção de instituição é externamente fecunda, uma vez que ela permite compreender a 
exigência ética inerente ao problema do humanismo. Todavia, este último está longe de ser evidente à primeira vista. Por que falar de uma implicação ética da instituição no nível político?

O conceito de instituição tem essencialmente um papel, como afirma Merleau-Ponty no começo dos cursos de 1954: ser um remédio às filosofias da consciência, uma arma contra o dualismo (MERLEAUPONTY 2003, p.123). Compreende-se a importância desta saída do dualismo, do ponto de vista da história da filosofia. Mas, no quadro da política, vê-se menos de que maneira o conceito de instituição permitiria fornecer uma ética nova. Além disso, seu papel é o mesmo? A definição de instituição nas Notes de Cours faz dela, de fato, um conceito essencialmente descritivo. Merleau-Ponty mostra que a instituição pode ser uma noção operatória na explicação a posteriori de certas experiências psicológicas, artísticas, filosóficas ou históricas. Mas não se vê no que esse conceito poderia definir uma conduta política qualquer.

A implicação ética aparece tão menos evidente quanto o conceito de instituição não parece abrir sobre uma distinção entre o bem e o mal. Como, desde então, distinguir as formas de regimes políticos de um ponto de vista ético ? Se se atém à estrita definição de instituição como "experiência por relação à qual outras experiências tomam um sentido» pode-se perfeitamente considerar uma ideologia totalitária com uma «instituição», se os homens são situados em relação a ela, quer eles tenham que lutar contra esta ideologia ou em seu favor. Por conseguinte, malgrado a proximidade das definições, o vínculo da instituição com o problema ético do humanismo não é evidente.

Entretanto, no percurso de uma passagem do prefácio de Sinais, Merleau-Ponty deixa sobre esse assunto uma pista muito sutil. Escutemo-lo.

O mal não é criado por nós ou por outros, ele nasce no tecido que nós costuramos entre nós e que nos sufoca. Quais novos homens suficientemente fortes serão suficientemente pacientes para refazê-lo verdadeiramente? (MERLEAU-PONTY 2010, p.1582)

Sabe-se que o " tecido » designa em Merleau-Ponty, o vínculo simbólico e carnal que nos une uns aos outros. O tecido é o instituído. Ele corresponde aos valores, à cultura e aos princípios que nos partilhamos em um dado momento da história. Mas o mais importante talvez não esteja aqui. 


\section{4}

Ele reside, sobretudo, no apelo e na exortação de Merleau-Ponty a «refazer» esse tecido, em lhe dar uma vida nova instituindo-o novamente. $\mathrm{O}$ engajamento na instituição parece ser a condição necessária para a luta contra o mal político. Como compreender esta afirmação ?

Propor uma interpretação da citação precedente pressupõe uma digressão. Precisamos, em particular, voltar ao início do prefácio de Sinais e à concepção geral de história que propõe Merleau-Ponty. Segundo ele, a história e a política se caracterizam pela « esmagadora impressão de uma fissura sempre por refazer » (MERLEAU-PONTY 2010, p.1549). Quaisquer que sejam os valores simbólicos que nos ligam através dos grandes acontecimentos, suas efetividades acabariam por serem apagadas pelo tempo. Nós bem gostaríamos de compreender o perigo dos prejuízos políticos sobre outrem, conhecer os modos de pensamento e os riscos que eles vinculam, nos os reiteraríamos sem cessar, a despeito dos exemplos da história. Assim, escreve MerleauPonty, " os historiadores conservadores registram como algo claro a inocência de Dreyfus - e não são, por isso, menos conservadores» (MERLEAU-PONTY 2010, p.1550). Não haveria, portanto, lição de história, os valores seriam apagados pelo tempo e não teriam a realidade inelutável nem a eternidade que nós lhes emprestamos no momento em que aparecem. "A história jamais confessa» (MERLEAU-PONTY 2010, p.1550), escreve Merleau-Ponty. Sente-se de novo a inspiração maquiaveliana desta visão histórica que repõe no primeiro plano a contingência. Se a história é contingente, o que ela poderia confessar? Ela tem verdadeiramente um segredo se sua realidade não é diferente dos atos, das decisões e das escolhas que se desenham nas relações humanas? Nem força metafísica, nem dado transcendente, ela toma corpo através dos reencontros intersubjetivos. O tecido simbólico de que falava anteriormente Merleau-Ponty tem, portanto, uma existência pontual e em parte ilusória. Ele retém apenas um tempo, em função das crenças, dos mitos e das convicções políticas que nós criamos e que governam nossas relações. Para Merleau-Ponty, a única lição da história sobre o homem é que ela não tem nenhuma a oferecer.

Duas consequências políticas ligadas entre si resultam então dessa averiguação. A primeira reside na tentação da resignação e do desengajamento político. 
Para quê ter tido razão ontem contra o stalinismo, hoje contra Alger, para quê desenlaçar pacientemente os falsos nós do comunismo e do anticomunismo, e passar a limpo o que um e outro sabem melhor que nós, se essas verdades de amanhã não dispensam um jovem das aventuras do fascismo e do comunismo hoje, se elas são estéreis enquanto não são ditas de maneira política - nessa linguagem que diz sem dizer, que toca em cada um as molas da cólera e da esperança - e que não será jamais a prosa do verdadeiro? (MERLEAU-PONTY 2010, pp.1551-1552)

«Para quê... ?» Se a lucidez sobre os valores não tem mais sentido e se a política se resolve em uma luta de poder caricatural ou os princípios não passam de um pretexto, então em nome do quê se engajar? Para que lutar por valores, se eles são destinados a ser apagados pelo tempo? Esta visão da história poderia conduzir ao relativismo e à absurdidade de todo engajamento político. A segunda consequência esta ligada à precedente. $\mathrm{O}$ desengajamento de cada um e a ausência de implicação na política abrem a via ao autoritarismo. Merleau-Ponty mostra no prefácio de Sinais que o momento de hesitação sobre os valores e a resignação que ele provoca caminham junto com o retorno dos dogmas. Citemos, por exemplo, o perigo ditatorial que ele põe em evidência, desde que o problema do humanismo e a necessidade da instituição não são mais levados em conta pelos cidadãos:

Por todas as escalas imensos problemas aparecem: não são apenas técnicas que se há de encontrar, mas formas políticas, móveis, um espírito, razões de viver... É então que um exército longamente isolado do mundo na guerra colonial recai com todo seu peso sobre o Estado do qual supostamente depende. (MERLEAU-PONTY 2010, p.1550)

É no momento em que o problema do humanismo se coloca de modo agudo, quando o vínculo simbólico entre os homens está por reinventarse, que é preciso reencontrar as «formas políticas», os «móveis», um «espírito» ou uma «razão de viver». O corpo social é frágil e abre a porta às dimensões autoritárias do poder. É frequentemente mais fácil, com efeito, reencontrar a ilusão do vínculo social nos valores já presentes e mantidos pela força do dogma, da persuasão e mesmo da violência. 
Lembremos igualmente a prevenção de Merleau-ponty, contra o retorno dos dogmas religiosos, nesses momentos de hesitação.

Mas o mundo encara mais francamente às questões com as quais é trabalhado? Porque elas aventuram embaralhar as fronteiras do comunismo e do capitalismo, a Igreja dá o melhor de si para sufocá-las, retoma suas interdições esquecidas, condena outra vez o socialismo, se isso não é democracia, tenta reocupar as posições da religião do Estado, reprime por toda parte, a começar por suas próprias fileiras o espírito de pesquisa e a confiança na verdade. (MERLEAU-PONTY 2010, p.1551)

Estas questões, que "trabalham o mundo ", são, mais uma vez, aquelas do humanismo. Para Merleau-Ponty, a dificuldade da criação de um vínculo novo entre os homens deve ser enfrentada, mesmo se ela embaralha nossas referências ideológicas e os esquemas nos quais nos reconhecemos durante tanto tempo. Sem isso, nós retornaremos aos princípios que não podem mais federar os indivíduos, se não ao preço de uma restauração liberticida (liberticide) dos dogmas. A visão merleau-pontyana da história é, portanto, muito exigente. Ela sublinha a constante necessidade, para cada homem, de encarar o problema do humanismo, apesar da resignação inerente à contingência da história. Se não nos confrontamos mais com a dificuldade da relação humana, se o anseio de se refugiar nos valores metafísicos estabelecidos toma a dianteira do desejo de participar da instituição da política, o vínculo entre os homens é mantido pela coerção e autoritarismo.

Assim, esta visão da história explica a citação precedente, sobre o mal político. A contingência do vínculo humano impõe regularmente sua reconstrução. A um dado momento, os valores são mantidos apenas ao preço de uma certa forma de dogmatismo. Donde o caráter «sufocante " do qual falava Merleau-Ponty a respeito do tecido simbólico, mas também a propósito do dogma da Igreja na citação precedente. Este momento de sufocamento é o sinal que os valores que nos unem revelam sua parte de ilusão e de arbitrário; o sinal que o problema do humanismo, da relação com outro através de uma história comum se coloca segundo um novo dado; o sinal, portanto, da necessidade de instituir de novo. Quais homens serão suficientemente fortes para refazer esse tecido; dito 
de outro modo, para recolocar em marcha o processo da instituição? Tal era o apelo de Merleau-Ponty. Portanto, o mal não é, segundo ele, o resultado de uma ideologia, mas a consequência de uma resignação cidadã, de um abandono progressivo e consentido, em cada indivíduo, de sua liberdade política. Esta concepção abole toda possibilidade de explicação simplista do mal pela diabolização de um individuo e instaura a responsabilidade coletiva. Ela já estava implicitamente presente em certas inclinações de Merleau-Ponty, bem antes da escrita do prefácio de Sinais. Eis, por exemplo, sua análise do antissemitismo em La guerre a eu lieu, un texto de 1945.

O antissemitismo não é uma máquina de guerra montada por alguns maquiavélicos e abastecida pela obediência dos outros. Tanto quanto a linguagem ou a música, ele não foi criado por alguns. Ele se concebeu no oco da história. Os líderes e as forças elementares, o cinismo e a estupidez, esta concepção astuta e policial da história é finalmente ingênua: ela concede consciência demasiada aos chefes e escassa às massas. (MERLEAU-PONTY 2010, p.109)

Seria preciso sem dúvida muita lucidez e coragem para não ceder ao princípio do bode expiatório e abordar a questão do antissemitismo sob a forma da responsabilidade coletiva em 1945. Mas esta abordagem é bem a confirmação, que Merleau-Ponty pensou muito cedo, do mal político como o resultado de uma decomposição social consentida. Haverá sempre homens para explorar os momentos de hesitação sobre os valores e de resignação com o intuito de fundar um poder fora da norma. Mas o sucesso de seu projeto só é possível se nós deixamos a eles nossa liberdade de engajamento. Aqui, Merleau-Ponty define uma virtude política muito exigente, que vai além da virtude maquiaveliana. Por certo, a virtude é uma capacidade de adaptação, uma lucidez que implica poder se destacar de seus princípios e de suas certezas ideológicas quando as circunstâncias o exigem; mas seu objetivo é maior que o da mera tomada de poder. Para Merleau-Ponty, a virtude deve ser elevada «acima do oportunismo» (MERLEAU-PONTY 2010, p.1375) próprio ao homem ávido por governar. Ela é, de fato, "um meio de viver com outrem» (MERLEAUPONTY 2010, p.1366). Ela encarna a exigência de instituição da qual cada cidadão deve se fazer portador. Com efeito, não é isso que Merleau- 
Ponty quer dizer quando nos convida a uma "virtude sem qualquer resignação ", ao fim do prefácio de Sinais? A virtude reside na coragem de enfrentar, cada vez que se coloca, o problema da relação do homem com o homem, qualquer que seja a contingência dos valores. A tentação da resignação deve ser ultrapassada. Mais ainda: é justamente porque os valores são contingentes, pois nunca são dados nem eternamente estabelecidos, que a necessidade de nosso engajamento político é maior. $\mathrm{O}$ político está por fazer, apesar de seu enraizamento na imprevisibilidade da experiência de outrem. «A ideia de uma humanidade fortuita e que não há causa ganha é o que dá valor de absoluto à nossa virtude ", citamos mais acima. $\mathrm{O}$ conceito de "virtude sem qualquer resignação » dá a esta frase toda sua amplitude. A virtude merleau-pontyana, inspirada em Maquiavel, ultrapassa efetivamente o conceito de " prudência " do florentino, pois ela não concerne apenas ao futuro príncipe, mas a cada cidadão no uso exigente de sua liberdade política.

Precisamos agora concluir sobre o conjunto desta ética merleaupontyana: a expressão "virtude sem qualquer resignação » significa que é preciso aceitar a dimensão contingente e em parte ilusória do vínculo entre os homens, aceitar, portanto, que o problema do humanismo se coloca ininterruptamente sob uma forma nova na história e enfrentá-lo, sem ceder ao fatalismo. Pois o mal político não tem sua causa direta no nascimento de uma ideologia particular ; ele resulta sobretudo do desengajamento político e da resignação face à contingência dos valores. A originalidade, mas também a exigência e a dificuldade desta abordagem, é que ela distingue em parte o campo da ética política daquele da ideologia. Por certo, todo engajamento é ideológico porque ele se encarna necessariamente na defesa de determinados valores. Mas a ética do engajamento está além, ou, antes, aquém desses mesmos valores. Pois a ética política supõe, em primeiro lugar, uma capacidade de distância em relação às suas próprias convicções, quando a necessidade de instituir se coloca sob uma forma nova. Esta tomada de distância de Meleau-Ponty em relação a ideologia tem frequentemente conduzido a ver em sua filosofia uma falta de engajamento, precisamente porque ele não poderia aderir a uma teoria sem condição. Parece-nos, no entanto, que se trata do contrário. É justamente porque a ética merleau-pontyana não é, a princípio, ideológica, e que ela não aceita nenhum dado da história como uma 
evidência política, que ela chama todo homem a assumir ao máximo as necessidades de seu engajamento. Se engajar não é seguir a correnteza de princípios inscritos em uma suposta natureza do homem ou do mundo, mas participar da instituição de dimensões simbólicas capazes de inscrever os indivíduos num futuro comum. O engajamento verdadeiro supõe permanecer livre, mesmo quanto às suas virtudes e convicções. «Cláusula de política, escreve Merleau-Ponty, mas que poderia perfeitamente também ser a regra de uma verdadeira moral» (MERLEAU-PONTY 2010, p.1369).

1 Nós voltaremos um pouco mais adiante sobre a presença desse problema no texto La guerre a eu lieu, pois este ponto exige alguns desdobramentos. Em Pour la verité ou Autour du Marxis$m e$, por sua vez, já se observa que Merleau-Ponty valoriza a abordagem marxista do político, em razão de sua capacidade de responder ao problema do humanismo, isto é, de criar entre os homens um vínculo simbólico comum ; Cf. MERLEAU-PONTY 2010, p. 141.

2 Eis, por exemplo, duas passagens contraditórias : "Et les hommes offensent avec moins de circonspection quelqu'un qui se fait aimer que quelqu'un qui se fait craindre, parce que l'amour est tenu par un lien d'obligation qui est rompu, les hommes étant mauvais, dès qu'une occasion d'utilité propre se présente...» (MACHIAVEL 2000, p. 125). " Mais quand le prince se découvre gaillardement en faveur d'une partie, si celui auquel tu t'attaches vainc, quoiqu'il soit puissant et que tu demeures à sa discrétion, il t'est obligé et l'amour y est engagé, et les hommes ne sont jamais si malhonnêtes qu'ils t'oppriment, en donnant un tel exemple d'ingratitude.» (Id., ibid., p. 151).

3 Por certo, Merleau-Ponty fala em Les Aventures de la dialectique de um "novo liberalismo ». Mas o conceito de liberdade aqui evidenciado não tem nada em comum com aquele do liberalismo, porque ele coloca em primeiro plano não mais a liberdade individual fundada sobre o interesse, mas uma liberdade política, sempre voltada para a construção do vínculo simbólico unindo os homens numa mesma história.

4 Ver por exemplo o prefacio de Claude Lefort ao Humanisme et Terreur. (MERLEAUPONTY 2010, p. 167)..

\section{Referências bibliográficas}

MACHIAVEL. 2000. Le prince, trad. Marie gaille-Nikodimov, Librairie Général Française. 
200

MERLEAU-PONTY. 2010. L'Oeuvres. Paris : Gallimard, « quarto ». .2003. L'institution, la passivité. Notes de cours au Collège de France, 1954-1955. Paris : Belin. 